Threat it Constitutes" (pp. 56 ; Washington 6, D.C. : Linacre Press, Inc., 1949 ; 1.50 dollars), and nobody who reads it can remain in doubt of the evil effects of this drug, which is popularly known under the name of hashish, or Indian hemp. Hemp, says Dr. Wolff, has innumerable common names in various countries, and he relates that the hashish of the Middle East, the kif of North Africa (kif being Arabic for tranquillity or peace), the dagga of South Africa, the anascha of the U.S.S.R., the esrar of Turkey and Persia, the marihuana of Spanish-speaking America and the United States, and the maconha of Brazil are all names for the same substance, which has other names as well. Dr. Wolff discusses its uses, general effects, the value of experimental observations made with it, its psychopathic manifestations and relationship to crime and delinquency, the medicolegal problems that it creates and the use of it in the Latin American countries. After reading his pamphlet, it is indeed difficult not to agree with him that, while opium "cures and punishes like a god", there is no reason or excuse for the use of marihuana, which "has been closely associated since the most remote time with insanity, with crime, with violence, and with brutality". A bibliography of eighty-three references adds to the value of this pamphlet, which presents its facts so vividly and yet in language which everyone can understand.

\section{East African Industrial Research Board}

THE seventh annual report of the East African Industrial Research Board (Nairobi: 1s. 6d.), now operating under the East African High Commission, covers the year ended December 31, 1949, and records that investigations have largely been concentrated on projects already receiving attention. In the field of ceramics, much effort was given to the development of a clay glazing technique for domestic pottery which might lend itself to the production of decorated ware for markets overseas, and steps were taken towards the establishment of the export of high-grade refractory products. Work on bricks and roofing tiles continued, and a suggestion for bonding a natural diatomite, unfired block with sisal fibre for the production of insulating slabs has been adopted commercially. Besides supplying fertilizer by calcining rock phosphate and soda ash for field trials throughout East Africa, laboratory work on the composition of the product continued, as well as the study of the making of bricks from this mixture. Laboratory work on the extraction of pyrethrins from fresh flowers was completed, and some work carried out on the storage of fresh flowers and the so-called 'fermentation' of closely packed flowers, the analysis of undried flowers and the loss in dry material in drying pyrethrum flowers.

\section{National Foundation for Scientific Research, Belgium}

THE twenty-second annual report of the Belgian National Foundation for Scientific Research covers the year 1948-49 (pp. 185 ; Brussels : Fonds National de la Recherche scientifique, 1949). The scientific activities of the Inter-University Institute for Nuclear Physics have included photographic plate technique and cosmic ray studies, the separation of isotopes by thermodiffusion in the liquid phase, the preparation of uranium oxide, the metallurgy of uranium, preparation of pure graphite, geological applications of radioactivity, technique of thin photographic emulsions, preparation of fluorine and uranium hexafluoride, mass spectrography, nuclear isomerism, investigations on the secondary ionization caused by a stream of slow neutrons, and arrangements for obtaining very high temperatures. A report is included on the distribution of redioisotopes in Belgium and also on work during 1948-49 at the Jungfraujoch Scientific Station, under Prof. M. Morand. This has dealt with cosmic rays and the nuclear reactions they produce in photographic plates and has included the study of the essential properties of neutrons and protons of energy greater than that which can be attained with the most powerful cyclotrons or other generators. In addition to details of the membership of the various scientific committees, the report includes an analysis of the distribution of research grants made since the establishment of the Foundation and a list of the national research centres. Lists of recipients of grants, totalling 3,250,000 francs, during the year 1949-50 and including the research objectives are appended, together with a list, by recipients, of publications during 1948-49.

\section{National Central Library, London : Annual Report}

THE thirty-third annual report of the executive committee of the National Central Library (pp. 32 ; London: National Central Library, 1950) covers the year ended February 28, 1949, and records a smaller total increase of 10.43 per cent in the issues of books from or through the Library to all categories of libraries which it serves. Total issues were $\mathbf{9 3 , 7 4 5}$ as against 84,889 in $1947-48$, and, of these, 10,445 were to or from university libraries, 695 to or from Imperial or foreign libraries, and 9,405 to or from the libraries of government departments, research and industrial organisations, etc. Issues from the Scottish Centra] Library for Students were 15,717, as against 15,547 in 1947-48, and from the Irish Central Library for Students, 12,873 as against 13,082, while total issues of the adult class department, the stock of which was augmented by 3,584 volumes, increased from 12,652 in $1947-48$ to 18,123 . Reference is again made to the value of the Bureau of American Bibliography as a source of information about American books and periodicals, and to the increased assistance given by the outlier libraries, which lent 17,926 volumes during the year compared with 15,023 in the previous year. Work has progressed steadily on the union catalogue of books in the Russian languages in libraries in the United Kingdom, and compilation of a union catalogue of all German war-time periodicals held by British libraries has been commenced. There are arrears of approximately 443,000 entries still to be incorporated in the National Union Catalogue, but work has proceeded on the Union Catalogue of outlier libraries, and entries contributed to Union Catalogues total $3,639,963$ at the National Central Library, 885,181 in Wales, and 140,278 in Scotland. During the earlier part of the year, the British National Book Centre was still engaged largely in disposing of the remaining stocks of books and periodicals transferred in December 1946 from the Inter-Allied Book Centre, but later the staff proceeded to make systematic arrangements for its main task of co-ordinating the exchange of redundant material within Great Britain and between Britain and other countries. The Treasury grant-in-aid was increased from $£ 14,500$ to $£ 19,000$, including sum of $£ 1,000$ to compensate for the first stage in the discontinuance of the contribution from the Carnegie United King. dom Trust. 